\title{
A Comparison of the Application of Readability Formulas in English Translation Textbooks and Their Translations
}

\author{
Sholeh Kolahi (Ph.D.) \\ Dept. of English Language Studies, Islamic Azad University Central Tehran Branch, Iran \\ E-mail: sh-kolahi@iauctb.ac.ir
}

Hajar Khanmohammad (Ph.D.)

Dept. of English Language Studies, Islamic Azad University Central Tehran Branch, Iran E-mail: haj.khanmohammad@iauctb.ac.ir

Elaheh Shirvani (M.A.) (Corresponding author)

Dept. of English Language Studies, Islamic Azad University Central Tehran Branch, Iran

Tel: 98-912-819-8557_E-mail: elaheh_shirvani819@yahoo.com

Received: December 10, 2012 Accepted: December 27, 2012 Published: December 27, 2012

doi:10.5296/ijele.v1i1.2963 URL: http://dx.doi.org/10.5296/ijele.v1i1.2963

\begin{abstract}
The main concern of the present study was to compare the readability level of English textbooks for translation courses and their Persian translations using two readability formulas: the Gunning Fog Index (GFI) and the Flesch New Reading Ease (FNRE) Formula. To this end a corpus comprising five textbooks for translation studies and their Persian translations were chosen. The reason behind choosing these textbooks is that they are the only translation textbooks translated into Persian and they are sources frequently referred to, by lower proficient students. Two hundred and eighty four sample texts were chosen randomly and examined in terms of readability levels by GFI; one hundred and forty two sample texts from English textbooks of translation and one hundred and forty two sample texts which were the translations of the respective English sample texts. A total number of thirty sample texts which were chosen from two hundred and eighty four samples were also examined by FNRE
\end{abstract}




\section{Macrothink}

Formula; fifteen sample texts from English textbooks of translation and fifteen sample texts which were translations of the respective English sample texts. These sample texts were chosen randomly from the beginning, middle and end of each translation textbooks and its Persian translation. Based on the outcomes of the research the average difficulty using GFI of English textbooks of translation was 16.4 while the average GFI score of their Persian translations was 20.1. This means that Persian textbooks of translation are 3.7 grade levels above their English originals in terms of readability. According to Gunning (1968) the higher the, the less readable the text is. According to the results obtained by FNRE Formula, the average score of English textbooks was 46.006 while the average score of Persian translations was 19.240. According to Flesch (1949) the higher the FNRE score, the more readable a text is. The findings of the study showed that translation textbooks which have been translated into Persian are less readable than their English originals.

Keywords: readability, readability formulas, translation textbooks, Gunning Fog Index (GFI), Flesch New Reading Ease (FNRE) Formula 


\section{Introduction}

In the present fast developing world, transmitting scientific knowledge is of prime importance. Scientific textbooks are considered as one of the important sources of knowledge (Vinkler, 2002). Textbooks are categorized as informative texts with the aim of transferring the information contained in the source text to the target readers (Bell, 1991). Among these scientific textbooks are textbooks which are written about the theories of translation. In the past decades there has been a proliferation of translation textbooks (Munday, 2008). Universities around the world have set up departments for translation studies with the aim of training professional translators and interpreters (Munday, 2008). These departments offer various courses on translation. The main challenging issue for the translators and translator trainers is the choice of appropriate textbooks (Youlan, 2005).

Training high quality translators and interpreters demands high quality textbooks which can affect the entire system of education and curriculum design (Youlan, 2005). Translation textbooks are mostly written in English and European languages. In order to be widely used by scholars and students, these textbooks need to be translated into different languages.

According to (Levy, 1967, p. 145) "translation is a process of communication: the objective of translating is to impart the knowledge of the original to the foreign reader". Due to the technological change and globalization, translation became a prevalent and necessary activity in the current century. Translation process may cause the translated text to undergo many changes. One of these changes is hypothesized as indicating and measuring the readability level. Translation process may affect the readability level of the translated texts to some extent (Toury, 1989).

Due to the fact that learners can only benefit from textbooks that they can read easily, readability is considered as an important characteristic of a high quality textbook (Allington, 2002).

\section{Literature Review}

\subsection{Translation Textbooks}

In the last thirty years a number of textbooks on translation theory have appeared by the help of which translation profession has gained academic respectability (Larson, 1998). Scholars use translation textbooks for translator training purposes. Training high quality translators demands high quality textbooks. Youlan (2005, p. 193) states:

A translation textbook, then, often focuses on providing students with general knowledge. It fulfills the following functions: 1) it is a teaching tool for pedagogical purposes, 2) it is systematically organized to reflect the main points in translation studies, 3) it tends to be comprehensive, extending from general principles to guidelines, suggestions and hints, including translation strategies, similarities and differences between two or more languages, and possibly a number of translation exercises covering various features, and 4) it must be informative, operative, and enlightening, and leave enough space for the users' personal development. 
Stewart (2011) narrows down the definition of translation textbooks and defines translation textbooks as practical works on translation offering texts for practice, with commentaries and/or suggested translation.

As translation studies become internationalized, the field expands and the need for translation textbook arises (Stewart, 2011). To be unambiguous and informing, textbooks need to provide their readers with the ease of reading. Finding the right fit between students' reading ability and textbooks seems to be very important. Readability studies aim to analyze texts to find the right fit between students reading ability and textbooks' difficulties (Feathers, 2004).

\subsection{Readability}

Defining "readability" is not an easy task because various definitions of readability have been proposed by different scholars. As cited in Najafi (2010), Klare (1963) defines readability as: "ease of understanding or comprehension due to the style of writing" (p. 1).

McLaughlin (1969), the creator of the SMOG readability formula, believes that: "readability is the extent to which a class of people finds certain text understandable and comprehensible" (p. 640). This definition focuses on the interaction between the readers and the printed material.

Richard and Schmidt (2010) define readability as: "how easily written materials can be read and understood. Readability depends on many factors, including (a) the average length of sentences in a passage (b) the number of new words a passage contains (c) the grammatical complexity of the language used" (p. 482).

According to Dubay (2004, p. 7), "readability is what makes some texts easier to read than others". This definition of readability is in line with the purpose of the current study.

Considering different definitions of readability it can be concluded that many scholars consider readability and comprehensibility as the same phenomenon, although in practice there is a difference between readability and comprehensibility.

\subsection{Readability V.S. Comprehensibility}

There exists a great difference between readability and comprehensibility. Readability is an attribute of text while comprehensibility is an attribute of reader (Harrison, 1980; Jones, 1997). Readability focuses on textual difficulty whereas comprehensibility is concerned about the interaction among text, task, reader, and strategy variables. Readability may result in comprehensibility, but not necessarily (Mayer, 2003). This means that readability is a pre-requisite for comprehension.

Carrell, (1987) believes that "Comprehension is a complex concept which covers multiple behavioral and cognitive factors" (p. 27). It seems obvious that besides sentence length and vocabulary complexity there are also other factors which influence the degree of comprehension. Bachman (1991) believes that factors such as: vocabulary load, syntactic complexity, syntactic density, level of information, and topic progression can affect comprehension. 
Most of the drawbacks of readability formulas arise from considering readability and comprehensibility as the same phenomenon.

Due to the fact that texts which are not readable cannot be comprehensible, measuring readability level of texts is of prime importance if comprehension is intended. Considering readability is particularly important in textbook selection, because the final goal of reading textbooks is comprehension (Guzzetti, 2002). Readability of a text is measured by some procedures which are called readability formulas.

\subsection{Readability Formulas}

Authorities (e.g., Klare, 1984 \& Dubay, 2006) trace the initiation of readability formulas to the publication of Thorndike's The Teacher's Word Book in 1921. From that time many scholars proposed different readability formulas. The vast majority of these formulas are no longer in use. Klare (1984) defines readability formula as "a predictive device intended to provide quantitative objective estimates of reading difficulty" (p.684). Klare (1984) declares that these readability formulas use accounts of language variables in writings in order to predict difficulty for the readers. These formulas are predictive devices which do not need the readers' actual participation. The variables in these formulas need to have a relationship to different aspects of readable writing.

Since readability is considered as an important quality of texts, a number of researchers aimed at measuring the readability of different kinds of texts.

\subsection{Practical Researches on Readability}

Due to the rising need for scientific communication there was a growing endowment of practical readability measurement (Dale \& Chall, 1948). Many scholars and researchers were concerned about the measurement of readability of different types of texts (e.g. Jabbari \& Saghari, 2011; Maftoon \& Daghigh, 2001/1380; Bargate, 2012; Kithinji \& Kass, 2010, etc). Literature on readability can be classified into two types: comparative studies and non-comparative studies.

In the former type of readability research, the focus of attention is on the application of readability formulas on a multitude of materials ranging from abstracts and web pages to textbooks. Here some non-comparative researches on textbook readability are introduced because they shed light on the topic of the current study. These studies are as follows:

Plucinski et al (2009) conducted a research on the readability of introductory financial and managerial accounting textbooks. They analyzed readability of 3 financial and 3 accounting textbooks by the use of FRE Formula. The results of the study showed that varying readability levels exist among these textbooks although they are all taught in the same year of college.

Heilke et al (2003) used the Flesch-Kincaid Grade Level Index to measure the readability of introductory political textbooks. The researchers chose American government texts written by James MacGregor Burns as the corpus of their study and they measured the average readability levels across editions. Heilke et al (2003) found that the level of readability has 
increased over the years.

Another research in the field of readability is Brabston et al (1998). The researchers measured the readability level of introductory MIS (Management Information Systems) textbooks. The researchers used the following readability formulas in evaluating the introductory MIS textbooks, GFI, FRE Formula, Flesch Grade Level, Dale-Chall, SMOG Grade Level, and FORCAST Grade Level. Eleven texts which were considered as top ones were chosen as the corpus for analysis. This study showed that a text does not represent an "average" readability score but that each section may in fact be written at a slightly different readability level depending on the authors' desire to reach a more or less computer literate or experienced audience.

Bargate (2012) measured the readability of managerial accounting and financial management textbooks. For the purpose of the study, the researcher used FRE Formula, GFI and Cloze procedure to measure the readability level of 2 managerial accounting and 2 financial management textbooks. The results suggested that the readability formulas returned varying results, demonstrating that some of the textbooks were at a high level and the students had to be striving more to be able to read them.

Another non-comparative readability study was conducted by Cline (1972-73). He measured the readability level of college textbooks and the reading ability of the students who used them. In this study the readability of 17 textbooks was measured by the use of Dale-Chall readability formula. The findings of the study showed that readability level of these textbooks were above the reading ability of the students.

The second type of readability research is comparative readability studies. Comparative studies are those studies which compare the readability level of an original text with its translation. Toury (1989) believes that this kind of research "may well yield interesting insights, at least insights into similarities and dissimilarities in the ways that texts of both kinds are processed" (p. 48). Some of the comparative readability studies are as follows:

Jabbari and Saghari (2011) conducted a research on the readability level of English medical texts and their Persian translations using SMOG Formula and GFI. In this study, readability of 50 translated booklets and their corresponding texts in English were measured. The researchers found that there exists a significant difference between the number of multi-syllable words and readability scores in English medical texts and their corresponding Persian texts, but no significant difference was observed between the number of words and sentences in these two texts. The results of the study showed that English medical texts are more readable than their Persian translations.

Najafi (2010) conducted a research on the readability of literary texts for children translated from English into Persian and literary texts written originally in Persian. She chose 10 translated literary books written for children and 10 literary books originally written in Persian and she used GFI for measuring readability level of the respective books. The results of the study showed that there is no difference in the readability of translated children literature and the literature written for them in Persian. 


\section{MInstitute ${ }_{\text {Mink }}^{\text {Macrothink }}$}

Kithinji and Kass (2010) conducted a comparative study of the readability of texts written in English and their translations into Kiswahili, language that is spoken in Kenya. They used 10 pairs of consent forms (each pair containing one English form and its Kiswahili translation), or 20 forms in total, for this study. The results of their study showed that a readable English text does not necessarily result in a readable text once translated into Kiswahili.

Maftoon and Daghigh (2001/1380) conducted a research on the readability level of English texts on humanities and their Persian translations. They measured the readability level of 500 sample texts of 18 English books and their Persian translations. The books were on different topics such as sociology, psychology, linguistics, politics, history and management. They used GFI and FNRE Formula for measuring the readability level of respective texts. They found that GFI and FNRE Formula are also suitable for Persian texts. The results showed that there exist no great difference between the readability levels in English and Persian.

Dye (1971) investigated the effects of translating different types of French texts into English and how readability changed in the process of translation. The researcher used FNRE Formula as the measurement tool. The results showed that English translations were more readable than the original French texts.

According to the mentioned practical researches on readability, it can be concluded that readability has been the focus of attention since long time ago. Different scholars and researchers have applied readability formulas on different text types specially textbooks. Due to the importance of readability in educational settings, the current study aims to measure and compare the readability level of the translation textbooks in English and their Persian translations by the use of GFI and FNRE Formula.

\section{Method}

\subsection{Corpus}

In order to collect samples suitable for the current research, the researchers chose five English translation textbooks and their Persian translations which were rendered by different translators.

The reason behind choosing these five textbooks is that they are the only translation textbooks which have been translated into Persian. The corpus of the study is introduced in Tables $1 \& 2$ below.

Table 1. Description of the English corpus

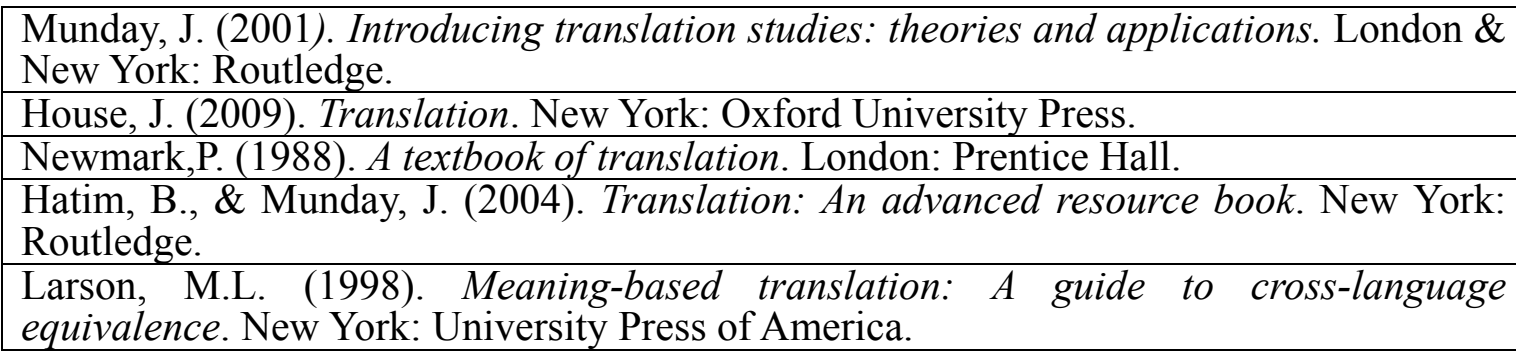




\section{Macrothink

Table 2. Description of the Persian translated corpus

Kashanian, H. (2005/1384). Ashnaee ba motaleate tarjomeh: Nazarieha va karbordha[Introducing translation studies: Theories and applications]. Tehran: Rokh

Bahrami, A. (2011/1390). Moghadamei bar motaleate zaban va tarjomeh [Translation]. Tehran: Rahnama

Fahim, M., \& Sabzian, S. (2009/1388). Doreye amoozeshe fonune tarjomeh [A textbook of translation]. Tehran: Rahnama

Jaber, M., \& Majidi, F. (2009/1388). Marjaee pishrafteh baraye tarjomeh [Translation: An advanced resource book]. Tehran: SAMT

Sichani, H, K. (2009/1388). Osool va mabanieh nazarieh tarjomeh [Meaning-based translation: A guide to cross-language equivalence]. Isfahan: Sanjesh Sepahan

\subsection{Instrumentation}

\subsubsection{The Gunning Fog Index}

Gunning (1952) proposed a readability formula which is known as "FOG Index". This formula is represented as follows:

\section{Fog Index/Grade Level $=0.4($ ASL + PHW $)$}

Where,

ASL $=$ Average Sentence Length (i.e., number of words divided by the number of sentences)

PHW $=$ Percentage of Hard Words

Scores obtained from Fog Index range from 6 to 17. The scores are presented in Table 3 below.

Table 3. The Fog Index with reading levels by grade

\begin{tabular}{|c|c|c|c|}
\hline \multicolumn{2}{|l|}{ Fog Index } & Reading Level By Grade & By magazine \\
\hline Danger Line & $\begin{array}{l}17 \\
16 \\
15 \\
14 \\
13\end{array}$ & $\begin{array}{l}\text { College graduate } \\
\text { College senior } \\
\text { College junior } \\
\text { College sophomore } \\
\text { College freshman }\end{array}$ & $\begin{array}{l}\text { No popular magazine } \\
\text { this difficult }\end{array}$ \\
\hline & $\begin{array}{l}12 \\
11\end{array}$ & $\begin{array}{l}\text { High-school senior } \\
\text { High-school junior }\end{array}$ & $\begin{array}{lcc}\text { Atlantic } & \text { Monthly } & \text { and } \\
\text { Harper's } & \text { Time } & \text { and } \\
\text { Newsweek } & & \end{array}$ \\
\hline $\begin{array}{l}\text { Easy-reading } \\
\text { Range }\end{array}$ & $\begin{array}{l}10 \\
9 \\
8 \\
7 \\
6\end{array}$ & $\begin{array}{l}\text { High-school sophomore } \\
\text { High-school freshman } \\
\text { Eighth grade } \\
\text { Seventh grade } \\
\text { Sixth grade }\end{array}$ & $\begin{array}{l}\text { Reader's Digest } \\
\text { Saturday Evening post } \\
\text { Ladies Home Journal } \\
\text { True Confession and } \\
\text { Modern Romances } \\
\text { Comics }\end{array}$ \\
\hline
\end{tabular}

The Gunning Fog Index, Gunning (1968, p. 40) 


\section{Ml Macrothink}

Scores above 17 are called 17+ and are considered beyond the danger line (Gunning, 1968). The most appropriate levels of difficulty seem to be between 13 and 17 for textbooks of translation because these textbooks are supposed to be taught to under-graduate students.

\subsubsection{The Flesch New Reading Ease Formula}

Flesch (1948) proposed a readability formula called Flesch Reading Ease (FRE). This readability formula uses a scale from 0 to 100 . The higher the score, the more readable a text is. The original formula is:

$$
\text { Reading Ease score }=206.835-(1.015 \times \text { ASL })-(84.6 \times \text { ASW })
$$

Where:

$\mathrm{ASL}=$ average sentence length (number of words divided by number of sentences)

ASW $=$ average word length in syllables (number of syllables divided by number of words)

FRE Formula became one of the most widely used, and the one most tested and a reliable one. In 1951, Farr, Jenkins, and Patterson simplified the formula further by changing the syllable count. The modified formula which is called the New Reading Ease reads as follows:

\section{New Reading Ease score $=1.599($ NOSW $)-1.015($ SL $)-31.517$}

Where:

NOSW $=$ number of one-syllable words per 100 words and

$\mathrm{SL}=$ average sentence length in words

Scores obtained by the FNRE range from 0 to 100. The scores are presented in Table 4 below.

Table 4. Flesch Reading Ease table

\begin{tabular}{|l|l|l|l|}
\hline $\begin{array}{l}\text { Reading Ease } \\
\text { Score }\end{array}$ & $\begin{array}{l}\text { Style } \\
\text { Description }\end{array}$ & $\begin{array}{l}\text { Estimated } \\
\text { Reading Grade }\end{array}$ & $\begin{array}{l}\text { Estimated Percent } \\
\text { of U.S Adults (1949) }\end{array}$ \\
\hline 0 to 30 & Very Difficult & College graduate & 4.5 \\
\hline 30 to 50 & Difficult & $13^{\text {th }}$ to $16^{\text {th }}$ grade & 33 \\
\hline 50 to 60 & Fairly Difficult & $10^{\text {th }}$ to $12^{\text {th }}$ grade & 54 \\
\hline 60 to 70 & Standard & $8^{\text {th }}$ and $9^{\text {th }}$ grade & 83 \\
\hline 70 to 80 & Fairly Easy & $7^{\text {m }}$ grade & 88 \\
\hline 80 to 90 & Easy & $6^{\text {ma }}$ grade & 91 \\
\hline 90 to 100 & Very Easy & $5^{\text {th }}$ grade & 93 \\
\hline
\end{tabular}

Flesch Reading Ease Score (Flesch, 1949, p.149) 


\subsection{Procedure}

\subsubsection{Gathering Data for the Gunning Fog Index}

In order to choose samples for the GFI, the researchers chose systematic sampling and selected a sample from every 10 pages of the English translation textbooks. The corpus of the study contained 284 sample texts; 142 English sample texts and 142 Persian translations of the English sample texts. The reason behind this kind of randomization is that Gunning (1968) believes that the samples should be spaced evenly through the whole text. Choosing samples from every other 10 pages makes it possible to have samples from the beginning, middle, and end of the books. Samples were chosen randomly from the respective pages.

English samples contain almost 100 words and the sentence count was stopped with the sentence which ends nearest 100 words total. From the examples presented in Gunning (1968, p.p. 207-240) it can be seen that the words occurring in samples can range from 86 to 137 depending on the spot where sentences end. In Persian samples, the sentence count was stopped where the translation of the English sample was finished.

For choosing samples from translated textbooks the researchers had to find the translation of each sample chosen from English textbooks. In some instances the translator(s) did not translate some lines or even whole paragraph(s) so the researchers had to read all the samples thoroughly and compare them with their translations. This was done to make sure that Persian translations are the exact translations of the English sample texts. In cases where the English sample was not translated, the researchers had to choose another sample text from the same page which was translated.

For choosing the samples the researchers skipped the first and last pages of all the textbooks which contained author's preface, translator's preface, table of contents, introduction and references. When the whole page contained tables or examples the researchers chose the sample from the previous or the next pages.

After selecting the corpus of the current study, all the elements included in the GFI were examined separately. The elements in the GFI were the number of words, the number of words with 3 and more syllables (polysyllabic words), and the number of sentences. Each sample was examined 3 times to count the above mentioned elements.

Counting the number of words in English was an easy task for the researchers because in English words are divided by the space between them and compound words are written together without any space, such as "bookkeeper" and also they are counted as one word. For counting the number of words in Persian, the researchers had to read some books on morphology and word formation to understand which compound words are counted as one word. Since this research is a comparative study and the rules illustrated in Gunning (1968) should be applied both in Persian and English, considering all Persian morphological rules could have changed the results of the formula. For this reason, in Persian like English, the space between the words was considered as the boundary for counting words.

In Persian words such as "مخلوط كن" (makhlut kon) 'mixer' and "“وردانه (rud khane) 'river' 
were counted as one word (Kalbasi, 2008/1387). Numbers were counted as one word too (Kalbasi, 2008/1387, p.31). Words containing "ها"ن (آن" (an), (at), "all three are plural markers' such as "دانشخاه ها:"(daneshgah ha) ‘universities'," "دان" (kudakan) 'children’

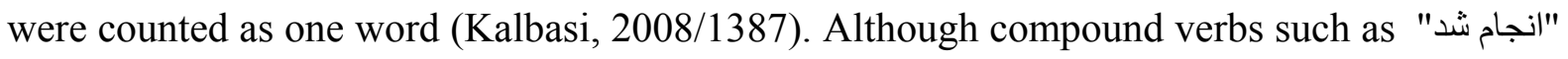
(anjam shod) 'was done' are considered as one word (Kalbasi, 2008/1387), in this study they were counted as 2 words because in English Gunning (1968) counted compound verbs such as "look up" and "go down" as 2 words. According to Gunning (1968) words containing a hyphen in between such as "ice-cream", "context-sensitive" and "culture-bounded" are considered as one word. So in Persian words such as "جتماعى- سياسى" (ejtemaee-siasi) 'social-political' were counted exactly as they were counted in English.

In English abbreviations such as "MT" (Machine Translation), "TL" (Target Language), and "e.g." (example) were counted as one word. In both English and Persian numbers and years were counted as one word and quotations which contained the year and page number were excluded from the word count.

When German and French words appeared in English and Persian samples, they were included in word count and for deciding whether they are polysyllabic words or not German and French online dictionary (http://dictionary.reverso.net/french-english) was used. In Persian texts English words are used either with their Persian equivalents or alone, in both cases the English words are included in word count and polysyllabic word count.

For deciding on polysyllabic words three rules are introduced in Gunning (1968) which are as follows:

1. Don't count the words which are the combination of easy words such as "manpower" and "bookkeeper"

2. Don't count the words which are made three syllables by adding "ed" and "es"

3. Don't count the words which are proper names

To apply rule number 1 in Persian, words such as "دانش آموز" "وفادارى" (vafadari) 'loyalty', (danesh amooz) 'student', "جانبدارى" (janeb dari) 'supporting', and "زيرنويس"(zir nevis) 'footnote' were not counted as polysyllabic words since they are combination of two easy words. In this case each easy words contained less than three syllables otherwise they were counted as two separate words.

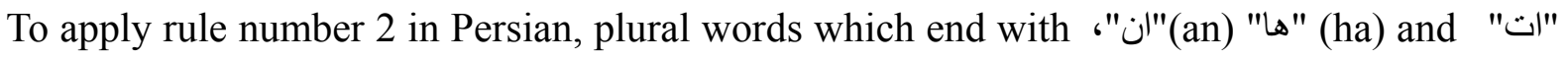

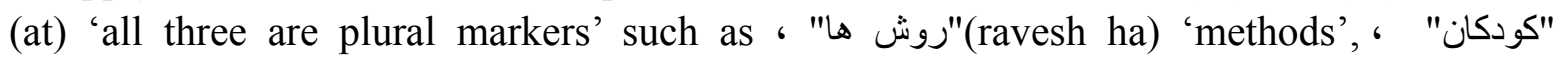
(koodakan) 'children', "توضيحات" (tozihat) 'explanations' were not counted as polysyllabic words but in cases where the word itself contains three syllables and by adding plural markers it becomes four or five syllables, the words are counted as polysyllabic words such as "ترجمه ها"(tarjome ha) 'translations', "مترجمان"(motarjeman) 'translators', and "طلاعات" (etelaat) 'information'.

Regarding rule number 3, "all the capitalized words, unless the reason for capitalization is that they begin a sentence", are excluded from the polysyllabic words count (Gunning, 1968, 
p. 281). For applying this rule in Persian the Persian equivalents of all English capitalized words were found and excluded from polysyllabic words count.

For counting the syllables in words the researchers looked up all the English words in online Merriam Webster Dictionary (www.merriam-webster.com/dictionary).

For counting the number of sentences no specific rule was suggested by Gunning (1968) so the researchers had to read all the sample texts presented in Gunning (1968) and analyze them carefully. In most of the samples, such as samples presented on pages 54, 55, 61, 62, $233 \ldots$, full stop indicates the end of sentence and the words between two full stops are considered as one sentence but there were exceptions to this rule as well. In two of the sample texts, such as those presented on pages 38 and 172, the words between two full stops are not necessarily counted as one sentence. This made it difficult for the researchers to decide on the number of sentences both in Persian and English. For solving this problem the researchers decided to consider "T-unit" as the basis for counting the number of sentences both in Persian and English sample texts.

As cited in Hirano (1989) The T-unit was first developed by Hunt (1965). Hunt (1970) has defined T-unit as "a main clause plus all subordinate clauses and non clausal structures attached to it or embedded in it" (cited in Hirano 1989, p.68). Hunt (1965) states that "each would be grammatically capable of being terminated with a capital letter (at one end) and a period (at the other)" (cited in Hirano, 1989, p.68).

\subsubsection{Gathering Data for the Flesch New Reading Ease Formula}

In order to choose samples for FNRE Formula, the researchers chose 3 sample texts (one from beginning, one from middle, and one from the end) from each of the English textbooks and their Persian translations. The reason behind choosing only 3 sample texts is following the exact suggestion of Flesch (1948).

English samples contain almost 100 words and the sentence count was stopped with the sentence which ends nearest 100 words total. In Persian samples, the sentence count was stopped where the translation of the English sample was finished. For choosing samples from translated textbooks the researchers had to find the translation of each sample chosen from English textbooks. In some instances the translator(s) did not translate some lines or even whole paragraph(s) so the researchers had to read all the samples thoroughly and compare them with their translations. This was done to make sure that Persian translations are the exact transference of the English sample texts. In cases where the English sample was not translated, the researchers had to choose another sample text from the same page which was translated.

After selecting the corpus of the current study, all the elements included in the FNRE Formula were examined separately. The elements in the formula were the number of words, the number of words of one syllable, and the number of sentences. Each sample was examined 3 times to count the above mentioned elements.

Counting the number of words was done exactly in the same way as was done for the GFI. 
For deciding on the number of sentences, like in the GFI, T-Unit was used.

\section{Results}

After applying the GFI and the FNRE Formula on the corpus of the study, the researchers found that the average GFI scores of English textbooks range from 13.2 to 17.5 and FNRE scores range from 30.031 to 54.015 . According to the Tables 4 and 5 this means that these textbooks are readable for university students.

Regarding the Persian translations, the average GFI scores of the translated textbooks range from 17.8 to 21.8. According to Table 3 this means that these translated textbooks are beyond the danger line and above the level of university students. The average FNRE scores of Persian translations range from 14.716 to 25.538 . According to Table 4 this means that the Persian translations are considered as "very difficult".

The difference between the GFI scores of English textbooks and their Persian translations ranges from 2.9 to 4.6. This difference indicates that Persian translations are between 3 to 4.5 grade levels higher than their original English versions in terms of readability. The higher the Fog Index, the more difficult a text is. The average difference between the FNRE scores of English textbooks and their Persian translations is -26.767 . This difference indicates that Persian translations are 26.767 scores lower than their original English versions in terms of readability. The lower the score, the more difficult a text is. The results of this study show that Persian translations of English textbooks of translations are less readable than their originals. The results are shown in table 5.

Table 5. Average Fog Index and FNRE Scores of English textbooks of translation and their Persian translations

\begin{tabular}{|l|l|l|l|l|l|l|}
\hline $\begin{array}{l}\text { Textbook } \\
\text { Number }\end{array}$ & $\begin{array}{l}\text { Average } \\
\text { Fog } \\
\text { Index of } \\
\text { English } \\
\text { Textbook } \\
\text { s }\end{array}$ & $\begin{array}{l}\text { Average } \\
\text { Fog Index } \\
\text { of Persian } \\
\text { Translation } \\
\text { s }\end{array}$ & $\begin{array}{l}\text { Differenc } \\
\text { e Between } \\
\text { the Fog } \\
\text { Indexes }\end{array}$ & $\begin{array}{l}\text { Average } \\
\text { FNRE } \\
\text { Scores of } \\
\text { English } \\
\text { Textbook } \\
\text { s }\end{array}$ & $\begin{array}{l}\text { Average } \\
\text { FNRE } \\
\text { Scores of } \\
\text { Persian } \\
\text { Translation } \\
\text { s }\end{array}$ & $\begin{array}{l}\text { Differenc } \\
\text { e Between } \\
\text { the FNRE } \\
\text { Scores }\end{array}$ \\
\hline$\# 1$ & 17.2 & 20.3 & +3.1 & 50.126 & 17.195 & -32.931 \\
\hline$\# 2$ & 17.3 & 20.7 & +3.4 & 46.388 & 19.5 & -26.888 \\
\hline$\# 3$ & 16.8 & 19.7 & +2.9 & 49.473 & 25.538 & -23.935 \\
\hline$\# 4$ & 17.5 & 21.8 & +4.3 & 30.031 & 19.250 & -10.781 \\
\hline$\# \mathbf{5}$ & 13.2 & 17.8 & +4.6 & 54.015 & 14.716 & -39.299 \\
\hline Average & $\mathbf{1 6 . 4}$ & $\mathbf{2 0 . 1}$ & $\mathbf{+ 3 . 7}$ & $\mathbf{4 6 . 0 0 6}$ & $\mathbf{1 9 . 2 4 0}$ & $\mathbf{- 2 6 . 7 6 7}$ \\
\hline
\end{tabular}

Note. Textbook number 1 is "Introducing Translation Studies: Theories and Applications" by Jeremy Munday and its Persian translation by Hamid Kashanian. Textbook number 2 is "Translation" by Juliane House and its Persian translation by Ali Bahrami. Textbook number 3 is "A Textbook of Translation" by Peter Newmark and its Persian translation by Mansoor Fahim and Saeed Sabzian. Textbook number 4 is "Translation: An Advanced Resource Book" 


\section{Macrothink}

by Bazil Hatim \& Jeremy Munday and its Persian translation by Maryam Jaber and Fariborz Majidi . Textbook number 5 is "Meaning-Based Translation: A Guide to Cross-Language Equivalence" by Mildred l. Larson and its Persian translation by Hadis K. Sichani. Complete description of the books is presented in Tables $1 \& 2$.

The above data is displayed in figures 1 to 12 below for easier reference.

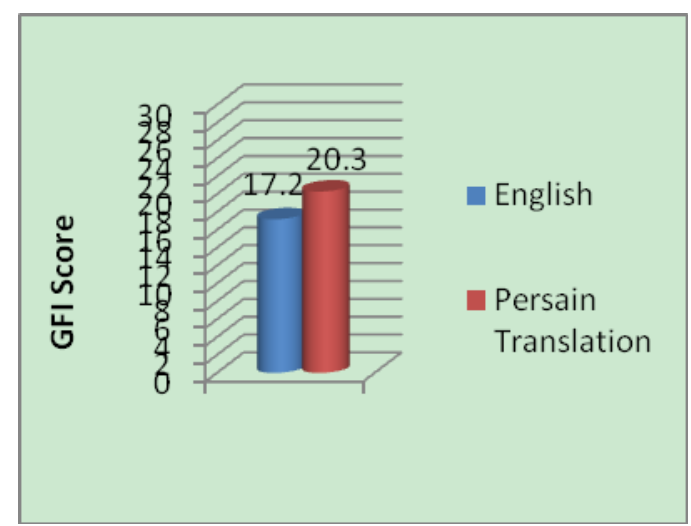

Figure 1. Average GFI score of the textbook "Introducing Translation Studies: Theories and Applications" and its Persian translation

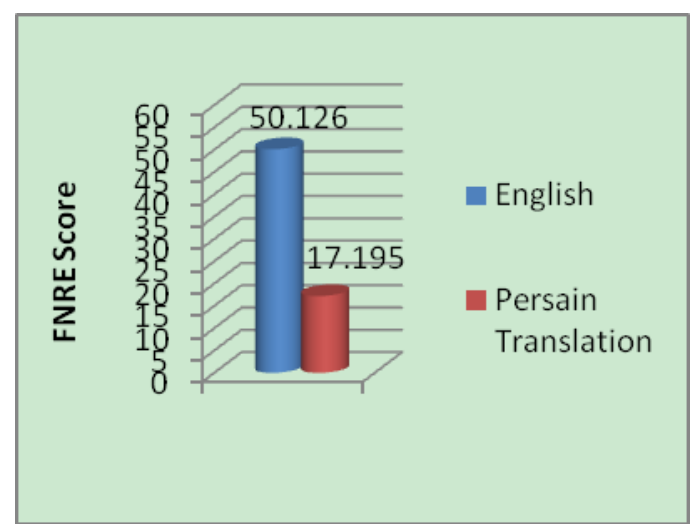

Figure 2. Average FNRE score of the textbook "Introducing Translation Studies: Theories and Applications" and its Persian translation

The average GFI score of English textbook of translation called "Introducing Translation Studies: Theories and Applications" is 17.2 while the average GFI score of its Persian translation is 20.3. The difference between these two scores is +3.1 which means that the Persian translation of this textbook is beyond the danger line and almost 3 grade levels above its English original. The average FNRE score of this English textbook is 50.126 while the average FNRE score of its Persian translation is 17.195. The difference between these two scores is -32.931 which means that the Persian translation of this textbook is less readable than its English original. 


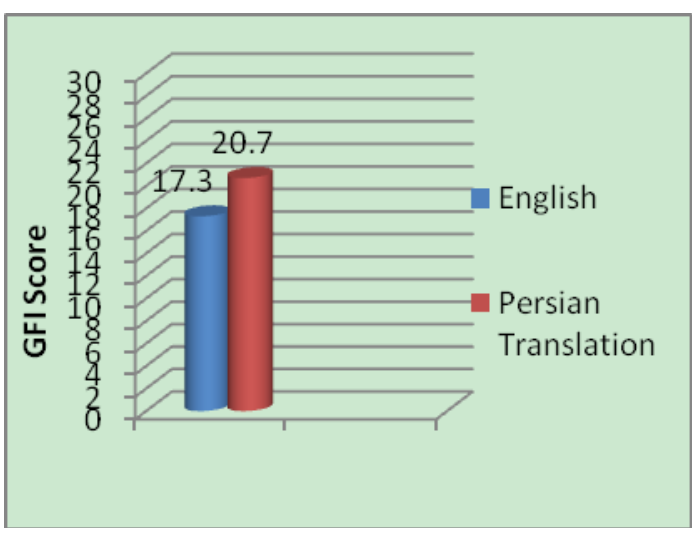

Figure 3. Average GFI score of the textbook "Translation" and its Persian translation

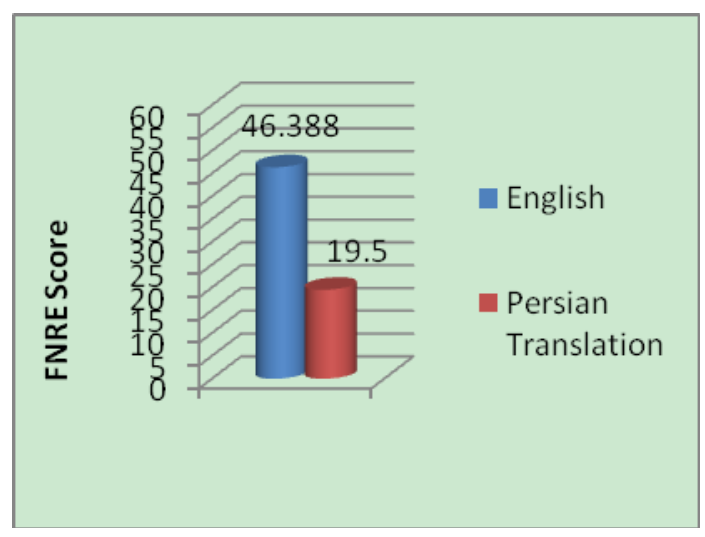

Figure 4. Average FNRE score of the textbook "Translation" and its Persian translation

The average GFI score of English textbook of translation called "Translation" is 17.3 while the average GFI score of its Persian translation is 20.7. The difference between these scores is +3.4 which mean that the Persian translation of this textbook is beyond the danger line and almost 3 grade levels above its English original. The average FNRE score of this English textbook is 46.388 while the average FNRE score of its Persian translation is 19.5. The difference between these two scores is -26.888 which means that the Persian translation of this textbook is less readable than its English original.

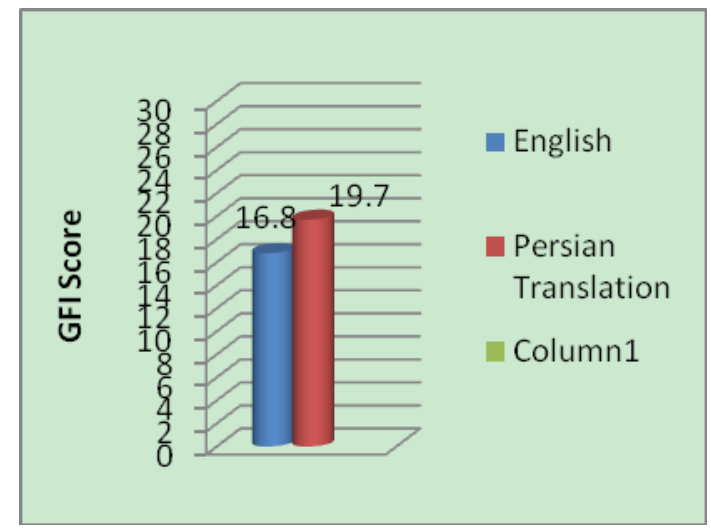

Figure 5. Average GFI score of the textbook "A Textbook of Translation" and its Persian translation

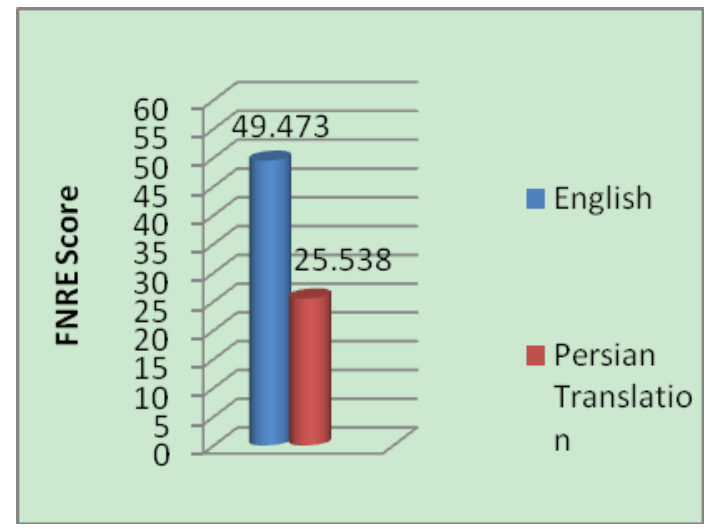

Figure 6. Average FNRE score of the textbook "A Textbook of Translation" and its Persian translation

The average GFI score of English textbook of translation called "A Textbook of Translation" is 16.8 while the average GFI score of its Persian translation is 19.7. The difference between 


\section{MInstitute ${ }_{\text {Mnk }}^{\text {Macrothink }}$}

these two scores is +2.9 which mean that the Persian translation of this textbook is beyond the danger line and almost 3 grade levels above its English original. The average FNRE score of English textbook of translation called "A Textbook of Translation" is 49.473 while the average FNRE score of its Persian translation is 25.538. The difference between these two scores is -23.935 which means that the Persian translation of this textbook is less readable than its English original.

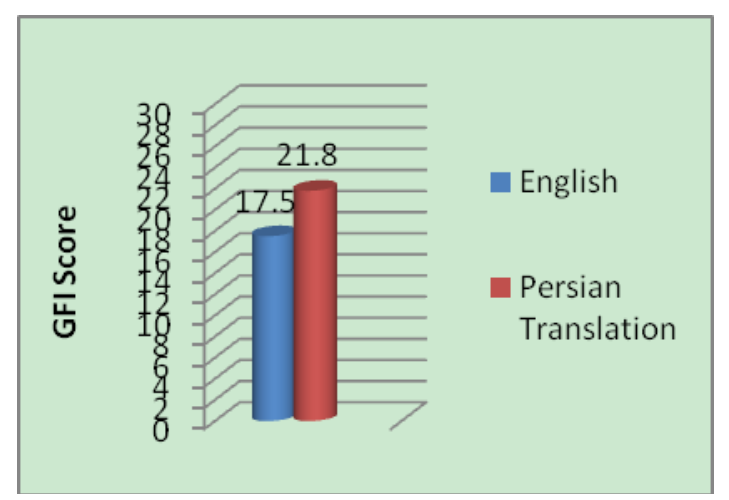

Figure 7. Average GFI score of th textbook "Translation: An Advance Resource Book" and its Persia: translation

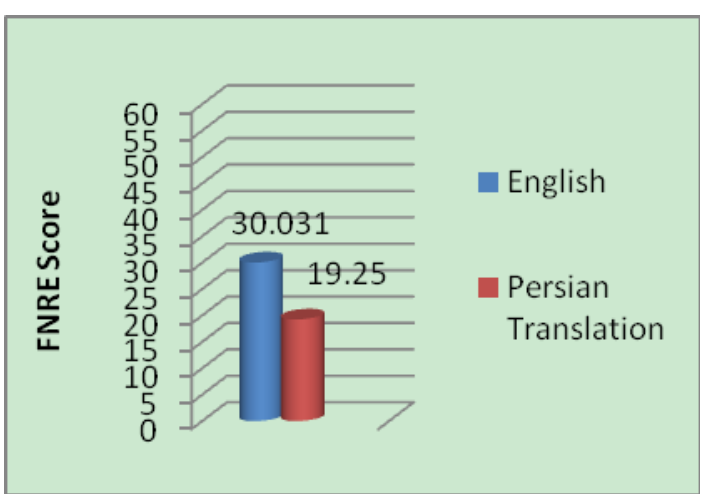

Figure 8. Average FNRE score of the textbook "Translation: An Advanced Resource Book" and its Persian translation

The average GFI score of English textbook of translation called "Translation: An Advanced Resource Book" is 17.5 while the average GFI score of its Persian translation is 21.8. The difference between these two scores is +4.3 which mean that the Persian translation of this textbook is beyond the danger line and almost 4 grade levels above its English original. The average FNRE score of this English textbook of translation is 30.031 while the average FNRE score of its Persian translation is 19.25. The difference between these two scores is -10.781 which means that the Persian translation of this textbook is less readable than its English original.
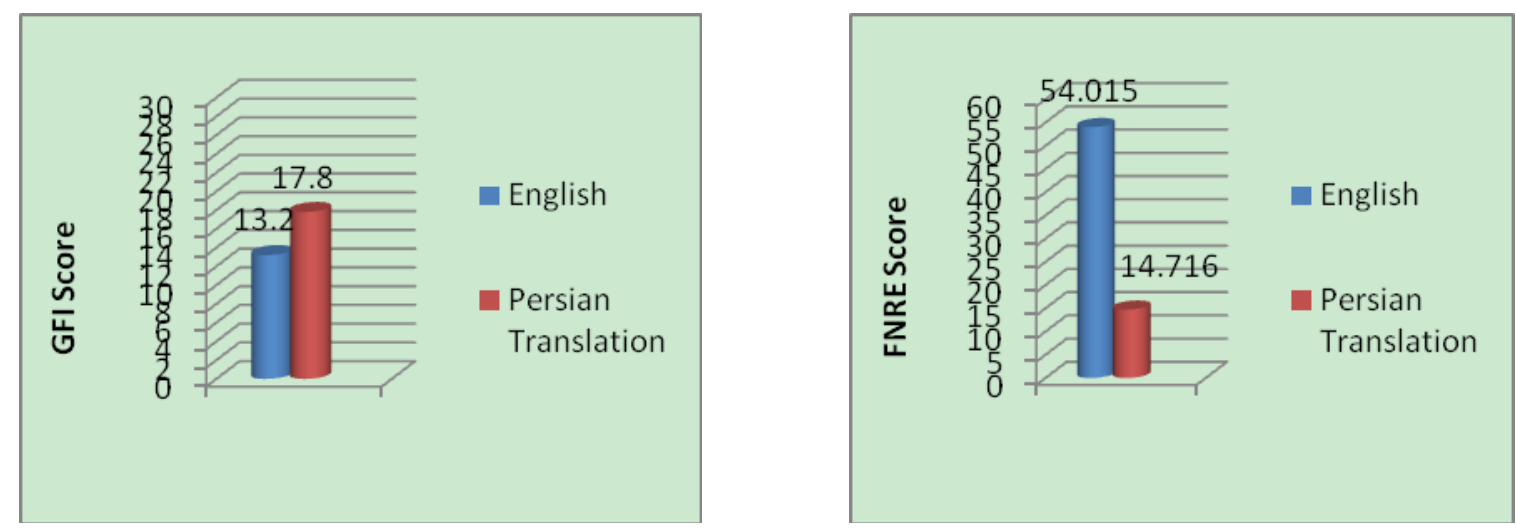
Figure 9 - Average GFI score of th textbook "Meaning-Based Translation: $t$ Guide to Cross-Language Equivalence and its Persian translation
Figure 10 - Average FNRE score of the textbook " Meaning-Based Translation: A Guide to Cross-Language Equivalence" and its Persian translation

The average GFI score of English textbook of translation called "Meaning-Based Translation: A Guide to Cross-Language Equivalence" is 13.2 while the GFI score of its Persian translation is 17.8. The difference between these two scores is +4.6 which mean that the Persian translation of this textbook is beyond the danger line and almost 4 and a half grade levels above its English original. The average FNRE score of this English textbook of translation is 54.015 while the average FNRE score of its Persian translation is 14.716. The difference between these two scores is $\mathbf{- 3 9 . 2 9 9}$ which means that the Persian translation of this textbook is less readable than its English original.

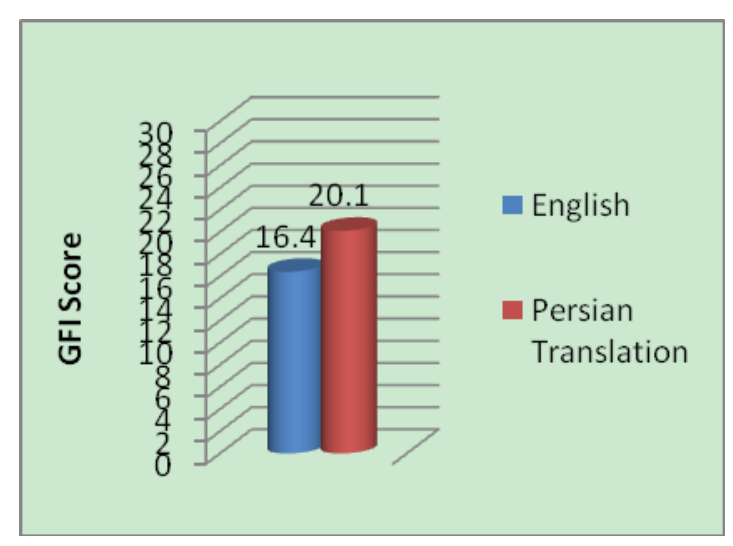

Figure 11. Average GFI score of the five English translation textbooks and their Persian translations

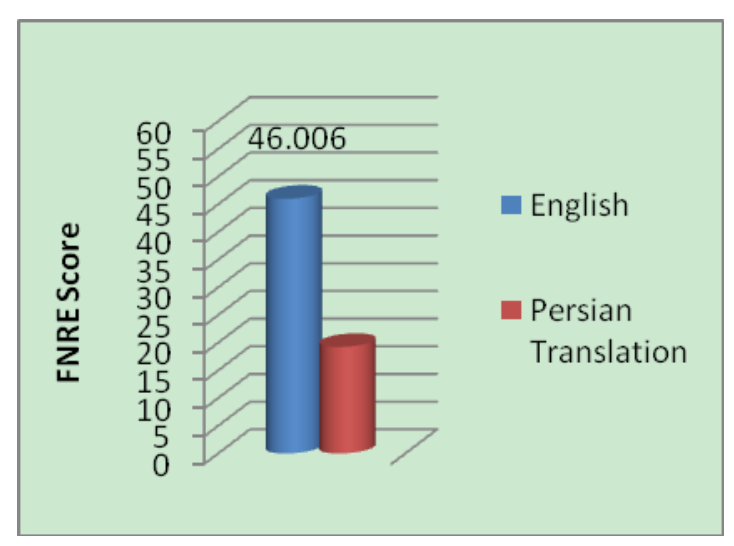

Figure 12. Average FNRE score of the five English translation textbooks and their Persian translations

Figure 11 shows the total average GFI score of all five English textbooks of translation compared to the total average GFI score of all five Persian translations. The results show that the total average GFI score of English textbooks is 16.4 and this number for the Persian translations is 20.1. The difference between the average GFI scores is +3.7 . This difference indicates that Persian translations are almost 3 and a half grade levels above English textbooks in terms of readability.

Figure 12 shows the total average FNRE score of all five English textbooks of translation compared to the total average FNRE score of all the five Persian translations. The results show that the total average FNRE score of English textbooks is 46.006 and this number for the Persian translations is 19.240. The difference between the average FNRE scores is 
-26.767. This difference indicates that Persian translations are less readable than their English originals.

According to the results obtained by both FNRE Formula and the GFI, it can be concluded that English textbooks of translations are more readable than their Persian translations.

\section{Discussion and Conclusion}

The present study attempted to investigate the difference between the readability levels of English textbooks of translation and their Persian translations by the use of the Gunning Fog Index and the Flesch New Reading Ease. The results of the analysis of the data obtained from the corpus demonstrated that Persian translations of English textbooks of translation are less readable than their English originals.

The results of the current study are in line with the results obtained by Jabbari and Saghari (2011) and Kithinji and Kass (2010) and contradictory to the results obtained by Maftoon and Daghigh (2001/1380) and Dye (1971). Jabbari and Saghari (2011) and Kithinji and Kass (2010) found that translation process affects the readability level and the translated texts are less readable compared to their originals. Maftoon and Daghigh (2001/1380) found that there exists no difference between the readability levels of English texts and their Persian translations. Dye (1971) also found that when translating from French into English, the translated texts are more readable than their originals.

Regarding the results of this study about the issue of change of readability in the translation process, the researchers came to the interpretation that the change in the readability level of English textbooks of translation and their Persian translations can be due to two factors; the nature of Persian language and the process of translation.

Different languages have different natures. Since the variables in the GFI and FNRE Formula are language dependent, this nature may affect the results obtained by the two readability formulas.

The process of translation is another reason for the change in the readability level of English translation textbooks compared to their Persian translations. Translated texts contain more words than their originals. One reason for using more words may be explicitation procedure used in translation. Since the number of words in a text is a variable in both the GFI and FNRE Formula, the change in the number of words can change the readability level.

In translation, the translator is faced with the dilemma of choosing the right equivalent for the word used in the source text. Sometimes this choice is toward hard words or words of three syllables or more. The higher the number of hard words, the more difficult a text is.

The unit of translation in nonliterary texts is sentence (T-unit). Sometimes two or more sentences of the source text are linked together and translated as one sentence. The lower the number of sentences, the more difficult a text is.

The present research endeavored to shed light on the issue of change in the readability level which may occur in translation process. The findings of this research can help the scientific 
textbook translators particularly those involved in translating translation textbooks from English to Persian to have a background perception about the change of readability in translation and let them make up their minds whether to take steps for translating them or not. The present study might also have educational implication for students of Translation Studies to decide whether to use Persian translations of translation textbooks as a help for understanding the scientific concepts presented in the original textbooks or try to improve their knowledge of English in order to be able to read English translation textbooks without any need to refer to their Persian translations.

\section{Authors}

\section{Sholeh Kolahi}

She is Assistant Professor of Applied Linguistics at the Islamic Azad University, Central Tehran Branch. She has been teaching at undergraduate and graduate levels for years and has published and presented papers in national and international journals and conferences. Her main areas of research include SLA issues, ELT methodology, and translation studies.

\section{Hajar Khanmohammad}

She is an assistant professor of Applied Linguistics at Islamic Azad University, Central Tehran Branch. She has been teaching at undergraduate and graduate levels for almost 20 years, and has published and presented papers in local, national and international journals and conferences. Her main areas of research include SLA issues, ELT methodology, testing and assessment, and translation studies.

\section{Elaheh Shirvani}

She holds an MA in Translation Studies from the Islamic Azad University, Central Tehran Branch. She has been teaching English in different schools and institutes in Iran. Her research interests are translation, morphology and word formation.

\section{References}

Allington, R. L. (2002). You can't learn much from books you can't read. Educational Leadership, 60(3), 16-19.

Bachman, L. F. (1991). Fundamental considerations in language testing. New York: Oxford University Press.

Bargate, K. (2012). The readability of managerial accounting and financial management textbooks. Meditari Accounting Research, 20(1), 114-122. http://dx.doi.org/10.1108/10222521211234192

Bell, R. T. (1991). Translation and translating: Theory and practice. London: Longman.

Biber, D. (2006). University language: A corpus_based study of spoken and written registers. Amesterdam: John Benjamin B.V.

Brabston, M. E., Nixon, J. C., \& Helms, M. M. (1998). An evaluation of introductory MIS textbooks based on readability measures. Journal of Information Systems Education, Fall/Winter 1998, 29-34. [Online] Available: http://jise.org/Volume09/Pdf/029.pdf 
Carrell, P. L. (1987). Readability in ESL. Reading in a Foreign Language, 4(1), 21-40.

Cline, T. A. (1972-73). Readability of community college textbooks and the reading ability of the students who use them. Journal of Reading Behaivior, 5(2), 110-118.

Dale, E., \& Chall, J. S. (1948). A formula for predicting readability. Educational Research Bulletin, 27, 37-54.

Dubay, W. H. (2004). The principles of readability. California: Impact Information.

Dubay, W. H. (2006). Unlocking language: The classic readability studies. California: Impact information.

Dye, O, A. (1971). The effects of translatin on readability. Language and Speech, 14(4), 392-397.

Feathers, K. M. (2004). Infotext: Reading and learning. Toronto, Ontario: Pippin Publishing Company.

Flesch, R. (1948). A new readability yardstick. Journal of applied psychology, 32, 221-233.

Flesch, R. (1949). The art of readable writing. New York: Harper.

Gibbons, M., \& Johnston, R. (1974). The roles of science in technological innovation. Research Policy, 3, 220-242. http://dx.doi.org/10.1016/0048-7333 (74)90008-0

Gunning, R. (1952). The techniques of clear writing. New York: McGraw-Hill.

Gunning, R. (1968). The techniques of clear writing (Rev. ed.). New York: McGraw-Hill.

Guzzetti, B. J. (2002). Literacy in America: An encyclopedia of history, theory and practice (Vol. 1). California: ABC-CLIO.

Harrison, C. (1980). Readability in the classroom. New York: Cambridge University Press.

Heilke, T., Joslyn, M.r., \& Aguado, A. (2003). The changing readability of introductory political science textbooks: A case study of Burns and Peltason, government by the People. [Online] Available: http://kuscholarworks.ku.edu/dspace/bitstream/1808/1038/1/2879\%20.pdf

Hirano, K (1989). Research on T-unit measures in ESL. Bulletin Joetso University Education, $8(2), 67-77$.

Jabbari, A. A., \& Saghari, N. (2011). A Comparison between the Difficulty Level (Readability) of English Medical Texts and Their Persian translations. International Journal of English Linguistics, 1(1), 30-37.

Jones, K. H. (1997). Analysis of readability, interest level, and writing style of home economics textbooks: Implications for special need learners. Journal of Vocational Home Economics Education, 12(2), 13-24.

Kalbasi, I. (2008/1387). Sakht e eshteghaghiye vaje dar farsi e emrooz (The derivational 
structure of word in modern Persian). Tehran: Institute for Humanities and Cultural Studies.

Kithinji, C., \& Kass, N. E. (2010). Assessing the readability of non-English language consent forms: The case of Kiswahili for research conducted in Kenya. IRB: Ethics \& Human Research, 32(4), 10-15.

Klare, G. R. (1984). Readability. In P. D. Pearson (Ed.), Handbook of reading research (pp. 681-744). New York: Longman.

Larson, M. L. (1998). Meaning-based translation: A guide to cross-language equivalence. New York: University Press of America.

Levy, J. (1967). Translation as a decision process. In L. Venuti (Ed.), Translation study reader, (pp. 148-159). London: Routledge.

Maftoon, P., \& Daghigh, M. (2001/1380). Taeen e mizan e khanaee e tarjomehaye Farsi e motoon e Englisi. (Measuring the readability level of Persian translations of English texts). Research Journal of faculty of literature and Human sciences of Shahid Beheshti University, $29,61-80$.

Mayer, B. J. F. (2003). Text coherence and readability. Topics in Language Disorder, 23(3), 204-224. http://dx.doi.org/10.1097/00011363-200307000-00007

McLaughlin, G. H. (1969). SMOG grading- a new readability formula. Journal of Reading, 22, 639-646.

Munday, J. (2008). Introducing translation studies: theories and applications. London \& New York: Routledge.

Najafi, F. (2010). The comparative study of the readability of Persian translation of English literary texts for children and literary texts written for them in Persian. Unpublished MA thesis. Azad University Tehran Central Branch.

Plucinski, K. J., Olsavsky., \& Hall, L. (2009). Readability of introductory financial and managerial accounting textbooks. [Online] Available: http://www.freepatentsonline.com/article/Academy-Educational-Leadership-Journal/2190628 98.html

Richard, J. C., \& Schmidt, R. (2010). Dictionary of teaching and applied linguistics. London: Longman.

Stewart, D. (2011). Translation textbooks: translation into English as a foreign language. [Online] Available:

http://www.intralinea.it/reviewarticles/eng_more.php?id=959_0_51_0_M\%

Toury, G. (1989). Experimentation in translation studies: Achievements, prospects and some pitfalls. In S. Trikkonen-Condit (Ed.), Emperical research in translation and intercultural studies, selected papers of the TRANSIF seminar 1988 (pp. 45-66). Germany: Gutter Narr Verlag Tubingen. 


\section{Macrothink}

International Journal of English Language Education ISSN 2325-0887 2013, Vol. 1, No. 1

UNESCO (2005), A comprehensive strategy for textbooks and learning materials. France: United Nations Educational, Scientific, and Cultural Organization.

Vinkler, P. (2002). The institutionalization of scientific information: A scientometric model (ISI-S Model). Library Trends, 50(3), 553-569.

Youlan, T. (2005). Translation studies and textbooks. Perspectives: Studies in translatology, 13(3), 188-204. http://dx.doi.org/10.1080/09076760508668991

\section{Copyright Disclaimer}

Copyright reserved by the author(s).

This article is an open-access article distributed under the terms and conditions of the Creative Commons Attribution license (http://creativecommons.org/licenses/by/3.0/). 